\title{
A Revised Stratigraphy for the Pliocene and Lower Pleistocene Deposits of the Lower Rhine Embayment
}

\section{H.A. Kemna}

Institut für Geologie und Mineralogie, Universität zu Köln, Zülpicher Str. 49a, D-50674 Köln, Germany.

Email: ha.kemna@ies.de

Manuscript received: March 2005; accepted: August 2007

\begin{abstract}
The Plio-Pleistocene succession in the Lower Rhine Embayment was subjected to a thorough revision of existing stratigraphic concepts. The deposits were studied at key sites in the type area near Venlo and in the large open-cast mine Hambach in the southern part of the Lower Rhine Embayment by means of sedimentological, petrographical, as well as palaeo- and rockmagnetic methods.

The work has yielded improved insights of the drainage pattern and the Late Pliocene and Early Pleistocene depositional history of the region. As a result, a new comprehensive lithostratigraphical framework has been established.

Study of the succession at Hambach showed the occurrence of deposits of the Rhine, Meuse and a local river in the Lower Pleistocene part of the succession. Paleo- and rockmagnetic studies of the deposits marking the transition from Pliocene to Pleistocene indicate that the GaussMatuyama magnetic reversal occurs several meters above the top of the Reuver Clay at Hambach.

The study of the Lower Pleistocene succession in the type area has confirmed the recently new established lithostratigraphic framework of the Netherlands. As a consequence, the previous Dutch lithostratigraphic system which forms the basis of the chronostratigraphic subdivision of the Pliocene and Early Pleistocene of NW Europe has been proven to be inappropriate and should be abandoned. This chronostratigraphic framework is based on the interpretation of palynological data and was first established in the Netherlands during the 1960s. The new lithostratigraphic concept has revealed numerous contradictions with the chronostratigraphic framework. Based on these results it is proposed to abandon the chronostratigraphic subdivision of the Early Pleistocene in northwestern Europe.
\end{abstract}

Keywords: Lower Rhine Embayment, Pliocene, Lower Pleistocene, Lithostratigraphy, Chronostratigraphy, Heavy Minerals, Pollen Analysis, Palaeomagnetism

\section{Introduction}

The Lower Rhine Embayment (LRE, Fig. 1) reaches far into the Palaeozoic rocks of the Rhenish Massif and forms the northwestern branch of a Graben system extending from North to South throughout the European continent (e.g. Vinken, 1988). The base of the Tertiary occurs as deep as $-1500 \mathrm{~m}$ a.s.l. in the LRE. The LRE consists of a number of tectonic blocks, each with a distinct subsidence history (Ahorner, 1962) persisting in present times. Therefore, the thickness of the successions is predominantly controlled by tectonics. From Middle Pleistocene times onwards, the climatic and tectonic evolution of the area has led to terraced deposits of the river Rhine.
Knowledge on the Plio-Pleistocene time-slice in the LRE and adjacent areas is highly manifold (e.g. Meijer, 1998). The outstanding qualities of the large fluvial archive in the LRE, as well as a long research history, have produced many results concerning climate change, fluvial architecture and many other topics from Miocene times onwards. Upper Pliocene and Lower Pleistocene sedimentary records have become worldfamous. The LRE has, therefore, always played an important role in discussing the position of the Plio-Pleistocene boundary: The official GSSP (Global Stratotype Section and Point) at the Vrica section in Calabria, Italy, defines the Plio-Pleistocene boundary near the top of the paleomagnetic Olduvai event at about 1.85 Ma (Aguirre \& Pasini, 1985). In contrast to this, 


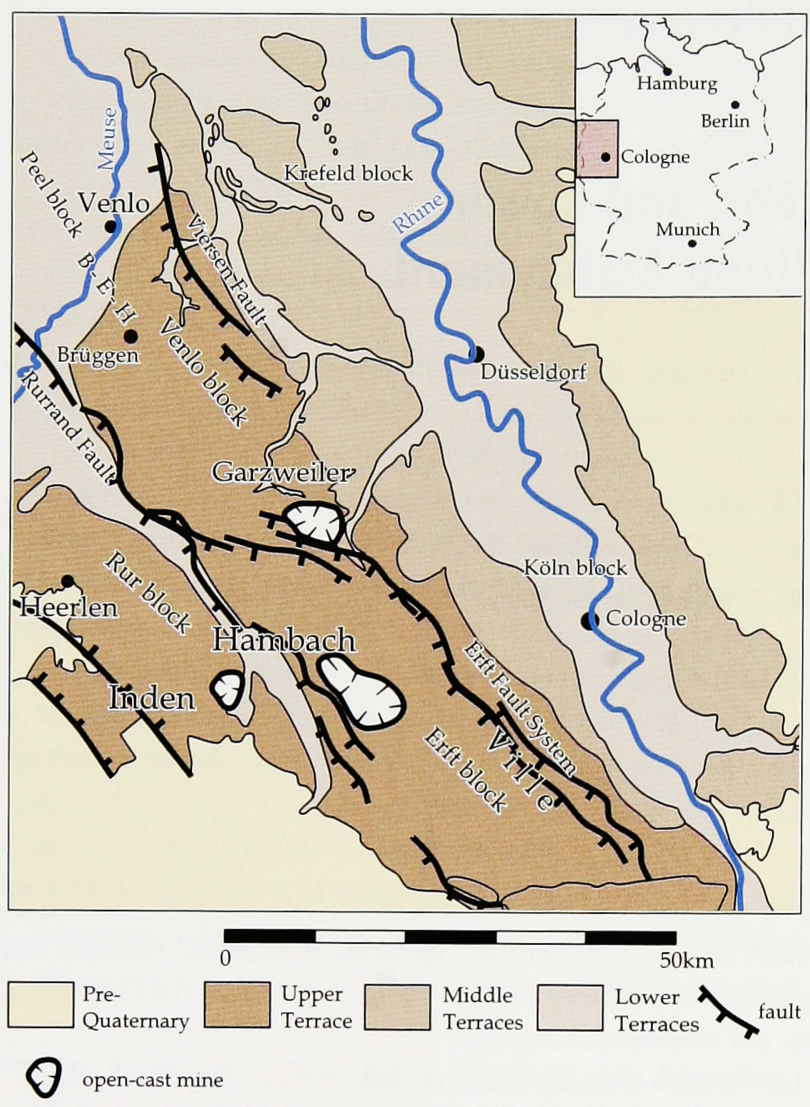

Fig. 1. The Lower Rhine Embayment (LRE) with tectonics and location of study areas; B-E-H: Brüggen-Erkelenzer Horst. The patterns display Rhine terraces only.

many scientists favour the beginning of the Quaternary to be located at the Gauss-Matuyama paleomagnetic reversal at approximately 2.65 Ma. This location of the Plio-Pleistocene boundary is unofficially used throughout NW Europe.

Apart from boreholes, most of our knowledge is derived from the classical exposures near Venlo in the North and from the large brown coal pits (open-cast mines) in the South. In recent years, the ever changing conditions of exposure have held good potential for new results; especially at the brown coal open-cast mine of Hambach, but also in the area near Venlo. Since research has been concentrated on the palaeontological record during the last few decades, investigations on lithostratigraphy have appeared promising.

The work presented hereinafter forms part of an integrated PhD study (Kemna, 2005). Other parts of it have been published elsewhere (Kemna \& Westerhoff, 2007; Westerhoff et al., 2008).

\section{Plio-Pleistocene stratigraphy}

The most relevant stratigraphical concepts are compiled in Fig. 2. Lithostratigraphy in the LRE is based on petrographic methods, i.e. analysis of heavy mineral and gravel content (e.g. Schnütgen, 1974; Boenigk, 1981a, 2002). For more information on methodology and application of heavy mineral analysis the reader is referred to Boenigk (1983) and Mange \& Maurer (1991).

There is also a concept based on a hydrogeological approach that was set up for the brown coal mining company RWEPower AG (formerly Rheinbraun AG; Schneider \& Thiele, 1965). In the latter concept coarse grained layers (aquifers) are given even numbers and fine grained layers (aquicludes) are given odd numbers.

The Pliocene is represented by deposits of the Kieseloolite Formation in the LRE. The white coloured, gravel-bearing sand of the Kieseloolite Formation predominantly contains stable heavy minerals such as zircone, rutile, anatase, and tourmaline, accompanied by the metamorphic mineral staurolite (the stable spectrum; Edelman, 1933; Zonneveld, 1947, 1958; Boenigk, 1970, 1981a, 2002). This material was deposited by an ancestor of the river Rhine (Palaeo Rhine) that drained the highly weathered overburden of the Rhenish Massif (Boenigk, 2002). In the southern LRE, the Kieseloolite Formation is represented by the 'Hauptkies' beds (stratum 8, according to Schneider \& Thiele, 1965), the 'Rot-Ton' beds (stratum 9) and the 'Reuver' beds (strata 10 and 11) including the Reuver Clay (stratum 11).

The Reuver Clay has commonly been regarded as the topmost member of the Kieseloolite Formation. It can be traced over a wide area in the LRE (e.g. Zagwijn, 1989). A petrographic study of the deposits of the Upper Pliocene Reuver Clay (Boenigk, 1970) showed that a distinct shift from stable heavy mineral spectra (typical for the Kieseloolite Formation) to unstable spectra with a predominance of garnet, epidote, alterite, and green hornblende (typical for the river Rhine being connected to the Alpine system; e.g. Boenigk, 2002) occurred during Late Pliocene times. Hence, two different units have to be distinguished: the 'Reuver Clay sensu stricto' (below, with stable heavy minerals) and an 'upper Reuver Clay' (with unstable heavy minerals). The 'Reuver Clay sensu stricto' represents the topmost member of the Kieseloolite Formation. In contrast, the upper unit cannot be assigned to the Kieseloolite Formation due to its unstable heavy mineral content. The name '0ebel beds' has been proposed for these deposits by Boenigk \& Frechen (2006) and will be adopted in the further course of this work.

Stratigraphy of the Lower/Early Pleistocene is highly complex because the drainage pattern gave way to several fluvial systems contributing to the deposition of sequences. However, they show a fragmentary preserved record. The Meuse entered the LRE from the Southwest in an eastward course during Early Pleistocene times (East Meuse river), and deposited sediments with an unmistakable gravel-content (angular flint stones and Revin quartzite; Kurtz, 1913; Breddin, 1955; Schnütgen, 1974; Boenigk, 2002) and a heavy mineral assemblage that is referred to as the metamorphic spectrum (predominance of stable minerals accompanied by staurolite and other metamorphic minerals; e.g. Boenigk, 1978). These 


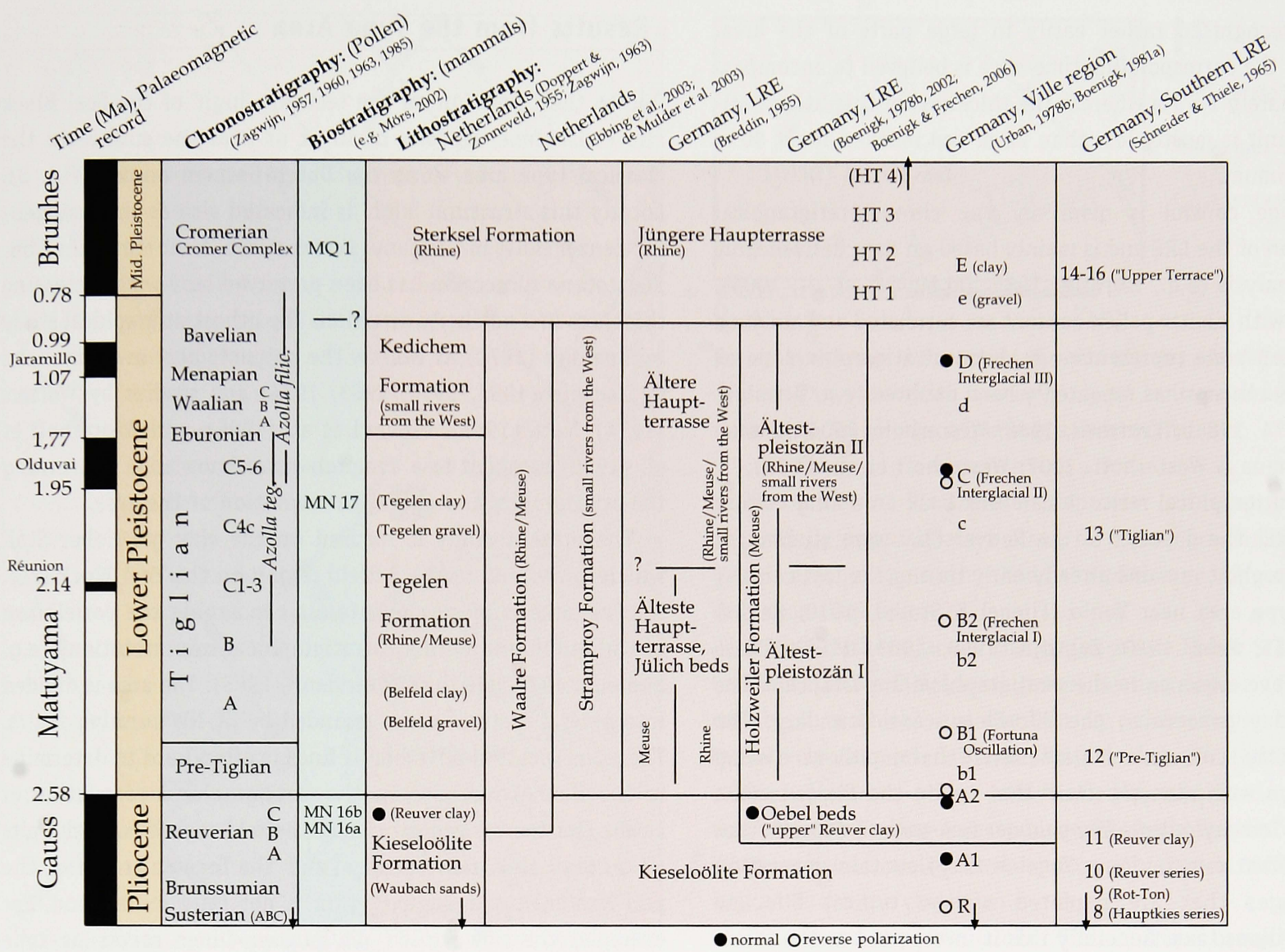

Fig. 2. Compilation of stratigraphical concepts relevant for the Plio-Pleistocene in the LRE. Palaeomagnetic time-chart according to Gibbard et al. (2004). Arrows indicate a higher/lower age than could be shown graphically; see text for further information.

deposits are assigned to the Holzweiler Formation (Boenigk, 2002) and form the entire Lower Pleistocene succession over a wide area in the middle LRE (for example at the open-cast mine Garzweiler).

At the same time the Rhine was connected to the Alps and deposited thick sequences with a characteristic gravel-content and unstable heavy mineral content in the southern LRE (Kowalczyk, 1969; Boenigk, 1978; strata 12 and 13 according to Schneider \& Thiele 1965). Downstream of the confluence of the two river systems, presumably situated near Düsseldorf, mixed Rhine-Meuse deposits were formed in the area near Venlo in the northwestern LRE. These deposits were called Tegelen Formation (including the Tegelen clay) in the type area near Venlo (Zagwijn, 1960; Zonneveld, 1958). Later on, this terminology became of widespread use to indicate Lower Pleistocene deposits throughout the LRE.

The drainage pattern during Early Pleistocene times (Boenigk, 2002; Kemna, 2005; Westerhoff et al., 2008) gave way to the deposition of reworked Tertiary marine sediments in the type area by small rivers coming from the West ('Scheldt catchment'; Kedichem Formation; Zonneveld, 1958). These sediments contain heavy mineral assemblages similar to those of the Holzweiler Formation (stable minerals with staurolite and other metamorphic minerals, i.e. the metamorphic spectrum). In the common stratigraphical concept for the south eastern Netherlands by Zonneveld (1955; Zagwijn \& van Staalduinen, 1975), these sediments overlie the Tegelen Formation.

A two-fold partition of the Lower/Early Pleistocene has been proposed by Breddin (1955) and Boenigk (1978). In the southern LRE (Ville region), the study of the Lower Pleistocene succession exposed in open-cast mines has led to a local lithostratigraphy using small letters for coarse grained deposits and large letters for fine grained ones (Boenigk, 1978).

A new lithostratigraphic system has been designed in the Netherlands (Ebbing et al., 2003; De Mulder et al., 2003). The newly defined Waalre Formation (defined by an unstable heavy mineral content and, thus, including the 0ebel beds) and the Stramproy Formation (defined by a metamorphic heavy mineral content) replace the older terms of the concept by Zonneveld (1958). The new system implicates a synchronicity of these two lithostratigraphical units by a large extent.

Over a wide area, the sequence of Lower Pleistocene deposits is overlain by deposits of the Middle Pleistocene Upper Terrace Sequence (Jüngere Hauptterrasse, subdivided into HT 1-4, Boenigk, 1978) The HT 2 unit corresponds to the Sterksel Formation in the Dutch lithostratigraphic system. Thus, the upper and lower boundaries of the Lower Pleistocene sequence 
can be recognised rather easily in large parts of the area. However, the corresponding time-slice is believed to encompass approximately 1.5 Ma whereas the thickness of this lithostratigraphic unit is mostly less than $20 \mathrm{~m}$ and reaches about $80 \mathrm{~m}$ as a maximum.

The age control is given by the chronostratigraphical subdivison of the LRE and is mainly based on data derived from pollen analysis (e.g., Zagwijn, 1985; De Mulder et al., 2003). Deposits with similar pollen content are correlated and assigned to a pollen zone representing a chronostratigraphic zone as well. This concept has repeatedly been doubted (e.g. Boenigk, 1970, 1974, 1981b; Krutzsch, 1988; Westerhoff, 2004; Kemna, 2005; Kemna \& Westerhoff, 2007; Westerhoff et al., 2008).

Biostratigraphical research can look back on a long history in the LRE. The deposits of the Reuver Clay were studied for the macro plant remains already early during the last century in the type area near Venlo (Fliegel \& Stoller, 1910; Reid \& Reid, 1915; Reid, 1920; Zagwijn, 1960, 1963, 1998). These studies gave evidence to the stratigraphical importance of the Reuver Clay concerning the Plio-Pleistocene boundary: The Reuver Clay contains characteristic thermophilous swamp vegetation with many species that typify the Pliocene (the so-called Tertiary relics). Any younger fine grained deposits that yielded plant remains (e.g. Tegelen Clay) contain vegetation assemblages that are depleted of the typical Pliocene thermophilous taxa. Generally this is interpreted as the result of a major change of the climate regime at the transition from Pliocene to Pleistocene.

Subsequently, the comparison of the Reuver Clay with overlying sediments by means of pollen-analytical (Florschütz \& van Someren, 1948; Van der Vlerk \& Florschütz, 1950, 1953; Zagwijn, 1960, 1963; Ashraf \& Mosbrugger, 1995, 1996), palaeomagnetical (Van Montfrans, 1971; Boenigk et al., 1972, 1974, 1978), and palaeontological methods (e.g., Schlickum \& Strauch, 1979; Gibbard et al., 1991; Van Kolfschoten et al., 1998; Tesakov, 1998; Mörs et al., 1998; Mörs, 2002) has confirmed that the top of the Reuver Clay is situated at about the Gauss-Matuyama boundary. Generally it is believed that this boundary marks the Plio-Pleistocene transition in NW Europe. A view that disregards the formal GSSP at Vrica, Calabria (Aguirre \& Passini, 1985).

Based on the lithostratigraphic system of Zonneveld (1958), the interpretation of pollen-analytical data obtained by Zagwijn $(1957,1960,1963)$ in the area south of Venlo has led to a highly detailed chronostratigraphical subdivision of the Pliocene and Early Pleistocene. This subdivision is widely used for the Northwest-European region (e.g., Gibbard et al., 1991, 2004). The distinctively cold-climatic stage of the Pre-Tiglian forms the lowermost stage of the Quaternary within the scope of this system. It is believed to be followed by the predominantly warm Tiglian (with several substages) and the cold Eburonian stage. The warm Waalian, the cooler Menapian and the Bavelian stages represent the younger part of the Early Pleistocene.

\section{Results from the Type Area}

Due to their position on the tectonic 'high' of the Peel Block Plio-Pleistocene deposits occur at or near the surface in the classical type area along the Dutch-German border (Fig. 3). Locally this structural 'high' is indicated also as the BrüggenErkelenzer Horst in Germany. Across several fault steps, the PlioPleistocene succession has been preserved here with increasing thickness in a northerly direction. The lithostratigraphical study by Boenigk (1970) as well as the palynological investigations by Zagwijn (1957, 1960, 1963, 1974) and studies by Wolters (1954), Nota (1956), Gibbard et al. (1995), and Westerhoff et al. (1998) have led to a comprehensive knowledge concerning the stratigraphy and geological evolution of the area.

The present study is focused on the clay pit Hoher Stall which is situated in the Belfeld region on the Peel Block (Fig. 3 ). This area is of special interest concerning the correlation of the Dutch and German stratigraphical interpretations (e.g. Boenigk, 1970, 1981b; Klostermann, 1983). The area is divided into several tectonic units bounded by SE-NW running faults. The exact location of the fault lines is often hard to determine in the field. Consequently, the stratigraphical correlation of Lower Pleistocene deposits in the Belfeld region (i.e., the pits Hoher Stall and Janssen-Dings) and the Tegelen area (i.e., the pits Maalbeek and Russel-Tiglia) is not fully understood. For example, the now closed pit Janssen-Dings serves as type locality for the so-called Belfeld gravel and Belfeld clay that are thought to represent respectively the Pretiglian and the earliest warm substage of the Tiglian (Tiglian A; cf. Zagwijn, 1963). However, these deposits are hard to recognise in the adjacent pits.

The stratigraphy of the Hoher Stall pit (Figs 4, 5) is the most complex one in the area. At its base it starts with the Reuver Clay typified by a blue-grey colour and two intercalated peat layers one of which at the top of the clay. The clay contains unstable heavy mineral assemblages (Boenigk, 1970). In contrast to other successions in the Venlo area (e.g. the clay pits Brachter Tonabbau and Oebel), the Reuver Clay at Hoher Stall does not overlie the deposits of the Kieseloolite Formation but is underlain by coarse grained sand deposits (up to $15 \mathrm{~m}$ thick) with an unstable heavy mineral content (Boenigk, 1970). However, the clay contains typical Pliocene pollen assemblages (Zagwijn, 1974; Westerhoff, 2004).

Lower Pleistocene deposits at Hoher Stall reach a thickness of approximately $10 \mathrm{~m}$ and consist of gravel-bearing sand that is assigned to the Tegelen gravel (Boenigk, 1970). This unit represents a mixed Rhine-Meuse deposit. Wolters (1954) referred to this unit as representing the deposits of the so-called Brüggen-Kaltzeit (Brüggen cold stage). Several clay layers occur super-imposed to this gravel. Deposits of the Belfeld gravel, as defined by Zagwijn (1963) at the clay pit JanssenDings nearby, cannot be distinguished lithostratigraphically from the Tegelen gravel. 

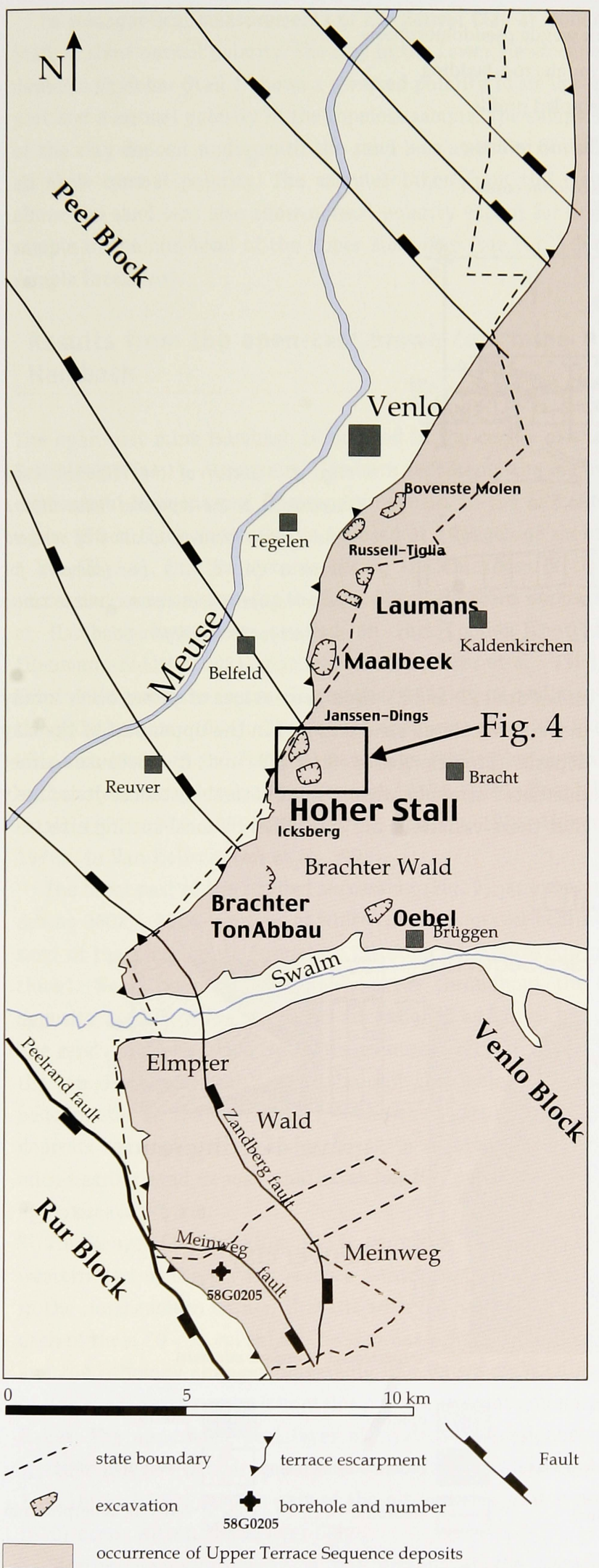

Fig. 3. Map of the type area of the Plio-Pleistocene in the Lower Rhine Embayment with tectonics, locations of described pits and of the Meinweg area. By courtesy of W.E. Westerhoff, Utrecht, modified.

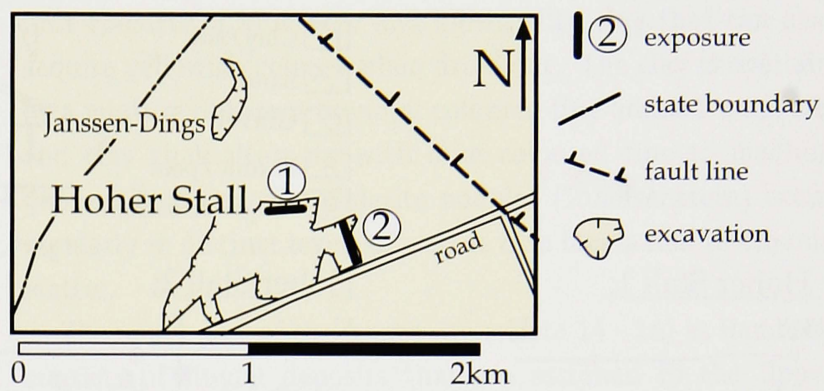

Fig. 4. Sketch map of the Belfeld area with the clay pits Hoher Stall and Janssen-Dings showing the location of logged and sampled exposures at Hoher Stall. The location of the map is given in Fig. 3.

These Lower Pleistocene deposits are unconformable overlain by approximately $10 \mathrm{~m}$ of coarse grained sand and gravel belonging to the Middle Pleistocene Upper Terrace Sequence (Fig. 5).

At the northern face of the pit (exposure Hoher Stall 1; Figs $4,5)$, the Lower Pleistocene gravel bearing deposits (approximately $2 \mathrm{~m}$ thick) are overlain by a clay layer that was tentatively correlated to the Belfeld clay (Westerhoff, pers. comm.). However, pollen-analytical data of this clay do not resemble any Tiglian-A assemblage (Westerhoff, pers. comm.). White coloured, well-sorted, quartz-rich sand occur below as well as above the clay layer.

The eastern exposure (Hoher Stall 2) shows a much thicker sequence of the Lower Pleistocene gravel bearing deposits of about $4 \mathrm{~m}$. An erosional horizon with clay clasts and white coloured, sand lenses is present in the mid-level of this unit. The Lower Pleistocene gravel bearing deposits here are overlain by a few meter thick clay deposit. Locally the clay is subdivided into two subunits by an intercalated brown coloured, gravel-free sand lens ( $0 \quad 1.8 \mathrm{~m}$ thick) which thins out quickly towards the South. The upper part of the clay deposit is eroded partly in the southern part of the excavation. Here, several small-scale channel-fills represent the uppermost part of the Lower Pleistocene succession.

The overlying deposits of the Upper Terrace Sequence reach a thickness of about $8 \mathrm{~m}$ at the Hoher Stall 2 section.

Eight 5 to $10 \mathrm{~m}$ long sections were logged and sampled for heavy mineral analysis (for location see Figs 4, 5; heavy mineral data are shown in Figs 6, 7). In addition, palaeomagnetic measurements were carried out on several samples from the fine grained units at the Hoher Stall pit.

The heavy mineral diagrams of Hoher Stall 1 (Fig. 6) show unstable spectra for the Reuver clay and the underlying sand (profile Hoher Stall 1A) as well as for the gravel bearing Lower Pleistocene deposits and the deposits of the Upper Terrace Sequence (profile Hoher Stall 1B). Metamorphic heavy mineral spectra are found in intercalated sand lenses of the clay deposit that overlies the Lower Pleistocene deposits here.

The heavy mineral diagrams of Hoher Stall 2 (Fig. 7) show repeatedly metamorphic heavy mineral assemblages within 


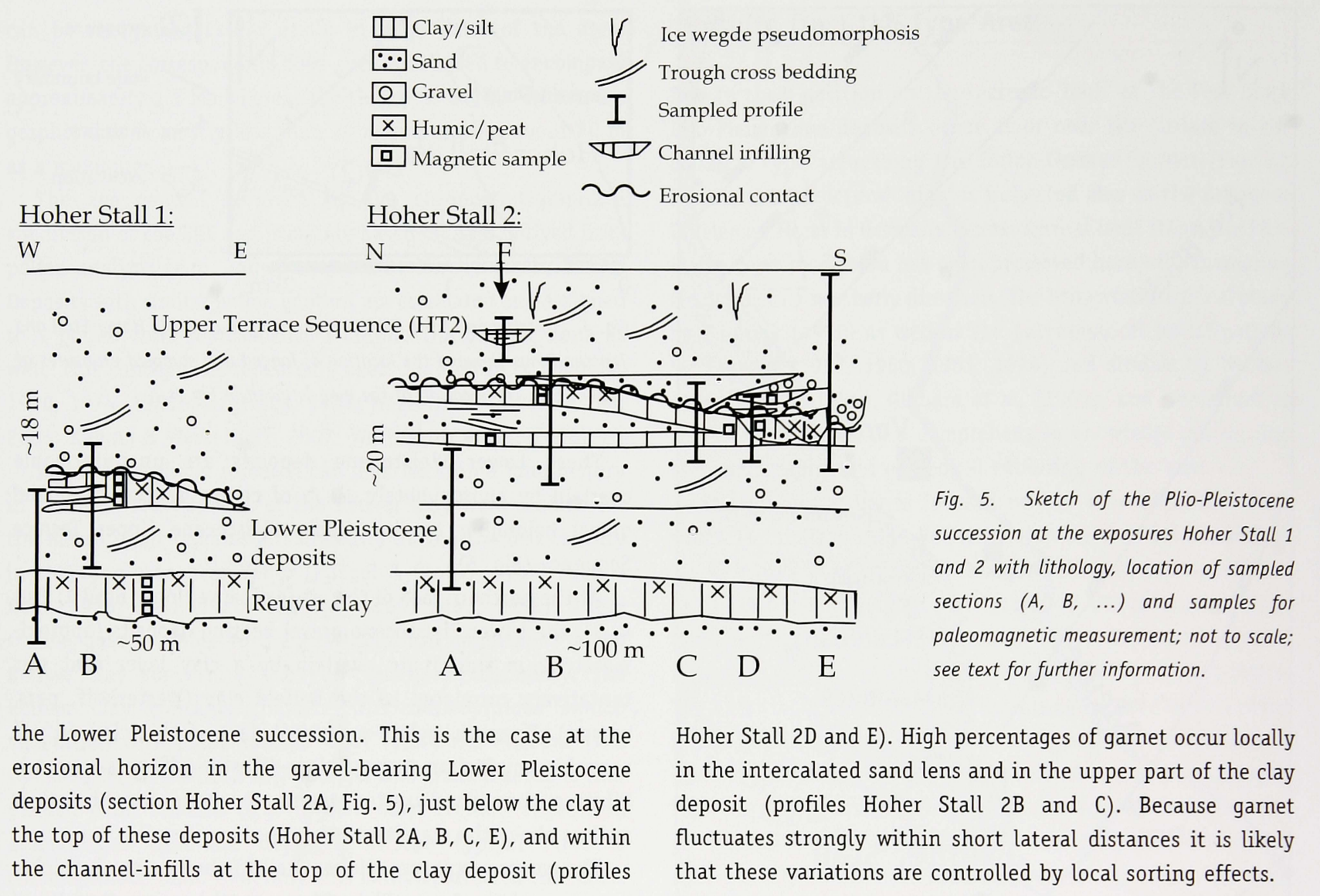

\section{Hoher Stall 1:}

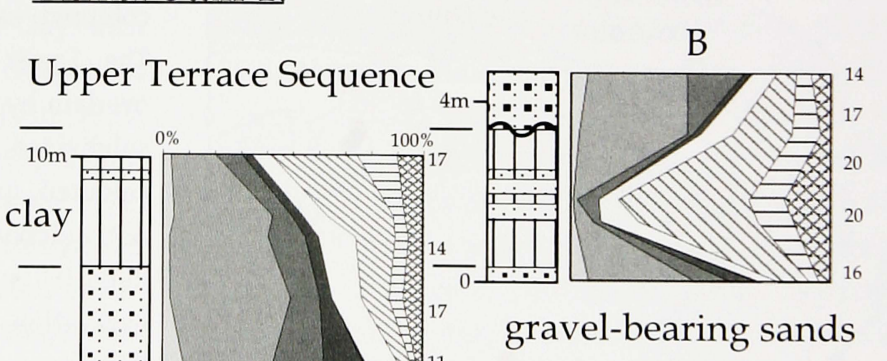

Fig. 6. Heavy mineral diagram of the exposure Hoher Stall 1. Unstable minerals (e.g., garnet) are plotted in the left-hand part of the diagrams. Metamorphic minerals (e.g., staurolite) are plotted in the righthand part together with the 'res' group, i.e., other minerals. Stable minerals (e.g., zircone) are plotted in the middle part of the diagrams. The percentage of opaque mineral grains is given at the right edge of the diagrams. The Reuver clay contains predominantly unstable heavy minerals ( $A$, left part of the diagram), as does the Upper Terrace Sequence. The Lower Pleistocene clay and the connected sands contain metamorphic heavy mineral spectra ( $B$, right part of the diagram). Note that the vertical interpolation between data points unintendedly suggests gradual transitions instead of sudden changes. 
Paleomagnetical measurements of the Reuver Clay at Hoher Stall all show normal polarity. The clay in the Lower Pleistocene deposits at Hoher Stall 1 shows a reversed polarity in its lower part and a normal polarity in the topmost sample. The samples of the clay deposit underneath the sand lens at Hoher Stall 2 all show normal polarity. The samples taken from the clay above the sand lens also show normal polarity except for one sample in the mid-level of the upper most clay (see Fig. 5 for sample locations).

\section{Results from the open-cast brown coal mine Hambach}

The open-cast mine Hambach is situated in the centre of the Erft block (Fig. 1). At present, Hambach represents the major exposure of Neogene and Quaternary deposits in the LRE. An up to $350 \mathrm{~m}$ thick succession is exposed at a length of about $5 \mathrm{~km}$ (Fig. 8). Due to tectonic tilting the thickness of the succession increases towards the East. Plio-Pleistocene deposits at Hambach have been studied on their pollen content (Heumann \& Litt, 2002), mammal remains (Mörs et al., 1998; Mörs, 2002), geochemistry (Hermanns, 1992), and sedimentology (Abraham, 1994). The former open-cast mines in the Ville area (Frechen and Fortuna) have been studied by several authors (a.o. Kowalczyk,1969; Boenigk, 1978, 1981; Boenigk et al., 1972, 1974, 1979; Schlickum \& Strauch, 1974; Urban, 1978a, b; Van Kolfschoten et al.,1998).

The basal part of the studied succession (Fig. 9), as exposed during 2002 - 2004, consists of white coloured, gravel-bearing sand of the Kieseloolite Formation (stratum 10, approx. $30 \mathrm{~m}$ thick). Wood fragments commonly occur throughout these deposits. Locally, these sediments are assigned as Reuver beds. The sandy deposits grade into light-coloured clay/silt towards the top. The uppermost part of the unit shows clear signs of pedogenesis. In the central part of the open-cast mine, these deposits are replaced by an up to $12 \mathrm{~m}$ of brown-coloured, mica-bearing sand deposit that stretches out over a length of approximately $1 \mathrm{~km}$.

The Reuver Clay (stratum 11) is approx. $4 \mathrm{~m}$ thick in the western part of the pit and reaches a thickness of up to $10 \mathrm{~m}$ in the northeastern corner. It starts with a double peat layer, each of them $20-50 \mathrm{~cm}$ thick. The clay has a blue-green colour and the lithology changes repeatedly into lenses and laminae of fine sand. Furthermore it contains mollusc remains and micaflakes. The uppermost peat layer of stratum 11 (assigned as stratum $13 \mathrm{~A}$ in the hydrogeological stratigraphy) can be up to $1 \mathrm{~m}$, thick. In the eastern part of the pit multiple peat layers $(>10)$ occur within the Reuver Clay.

Stratum 13 (stratum 12 is not present at the site) is thought to represent the Lower Pleistocene deposits at Hambach (Schneider \& Thiele, 1965). The thickness varies from $6 \mathrm{~m}$ in the southwest to about $50 \mathrm{~m}$ in the northeastern part of the open-cast mine (Fig.9). The lowermost part of the unit consists of blue-grey and brown silty clay that can also acquire yellowish colours when dried out. The clay is overlain by a mixture of brown to violet coloured fine grained sand, silt and clay that alternate with blue coloured fine to medium grained sand deposits. Siderite nodules (Toneisenstein) occur regularly in distinct levels as well as thin layers rich in organic matter.

The upper part of the succession (strata 14 - 16) at Hambach consists of fluvial deposits that are assigned to the Upper Terrace Sequence. The transition from stratum 13 to strata 14 16 is not always sharp at Hambach. Generally, strata $14 \quad 16$ start with coarse grained deposits locally followed by bluecoloured, fine grained channel-fills. Especially in the northeastern part of the open-cast mine the lower part of strata 14

16 shows up to $8 \mathrm{~m}$ thick clay and silt layers. Part of them is developed as stacked channel-fills.

Five sections from the first and second level (Fig. 9) of the exposure were logged and sampled for heavy mineral analysis, palaeomagnetic measurements as well as for a geochemical investigation. The results of heavy mineral analysis are presented for the sections Hambach 1 and 2. Palaeomagnetic data were obtained at the sections Hambach 3 and 4 .

The section Hambach 1 (approximately $23 \mathrm{~m}$ long, Fig. 10) is located in the south western part of the pit where subsidence was relatively low and therefore comprises a condensed succession. The lower part of the section shows predominant stable heavy mineral assemblages. The Reuver Clay shows unstable spectra with high values of garnet. The analysis of spot samples taken from the previously mentioned brown coloured, mica-bearing sands which underlie stratum 11 in the central part of the excavation, showed that these deposits contain unstable heavy minerals as well (Kemna, 2005). The according diagrams are not displayed separately in the present study for spatial reasons.

The Lower Pleistocene deposits of stratum 13 show associations of nearly $100 \%$ stable heavy minerals only. The transition to the deposits of strata $14-16$ is marked by a sudden change to predominant unstable spectra. Compared to the unstable spectra of stratum 11 the deposits of strata 14 16 show low values for garnet.

The profile Hambach 2 (approximately $44 \mathrm{~m}$ long) is derived from the nearly vertical face in the northernmost part of the open-cast mine. It covers the same succession as the profile Hambach 1 and extends from approximately $15 \mathrm{~m}$ underneath the upper boundary of stratum 10 (Kieseloolite Formation) to the upper part of strata 14 - 16 (Upper Terrace Sequence). The heavy mineral diagram (Fig. 11) shows stable spectra for samples taken from stratum 10. However, the lowermost sample shows a different picture. Here an influx of up to $40 \%$ unstable heavy minerals can be noticed within the deposits of the Kieseloolite Formation. Stratum 11 contains intermediate spectra with up to $20 \%$ of unstable heavy minerals in the lower part and increasing values up to about $90 \%$ in the uppermost 
part. The overlying, fine grained deposits of the lower part of stratum 13 show mixed associations of stable and unstable heavy minerals. These are overlain by coarse grained deposits that show spectra with metamorphic minerals and considerable amounts of brown hornblende (Vosges hornblende). The gravel content of these deposits contains angular flint stones and Revin quartzite, both characteristic features of Meuse deposits (Holzweiler Formation; Boenigk, 2002). With the exception of

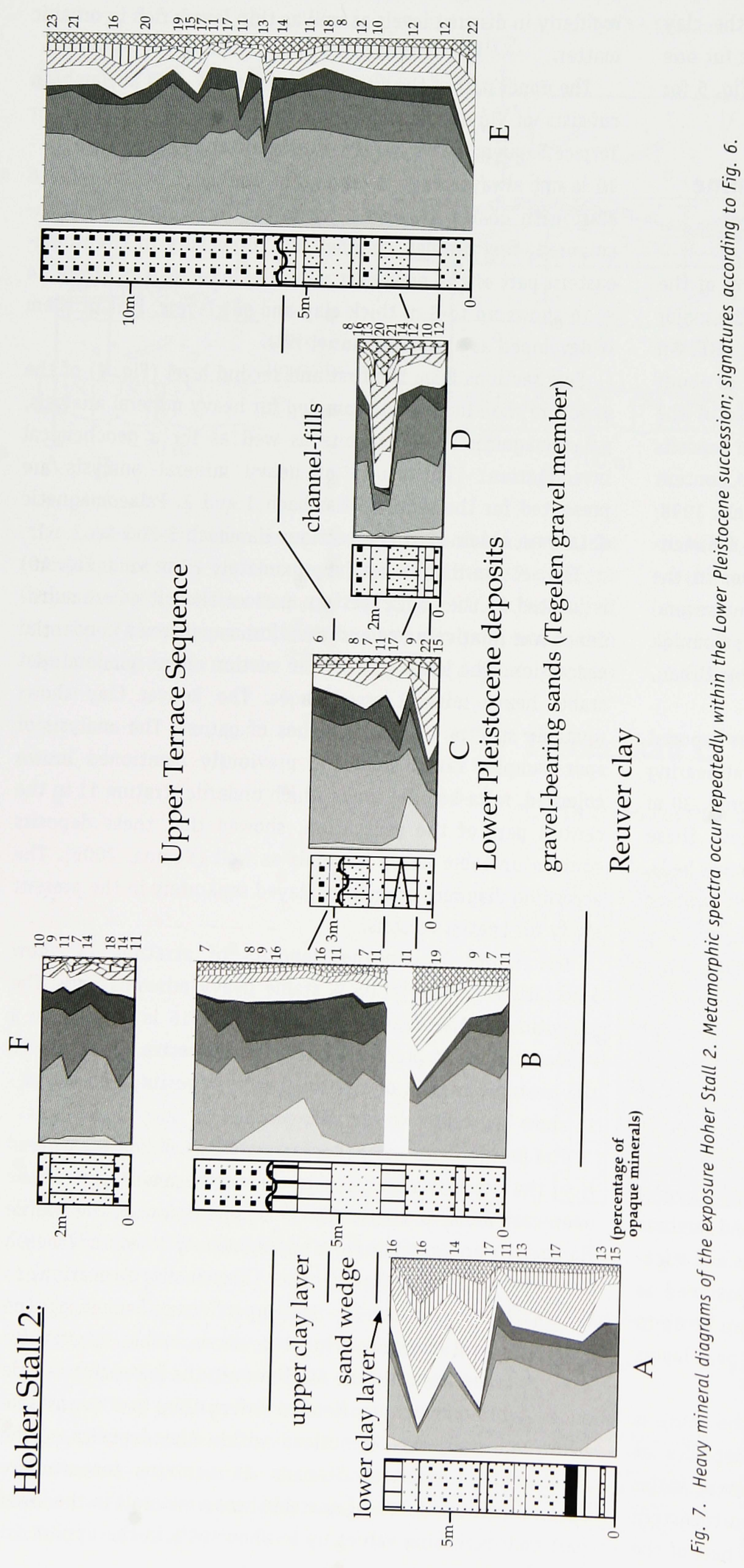




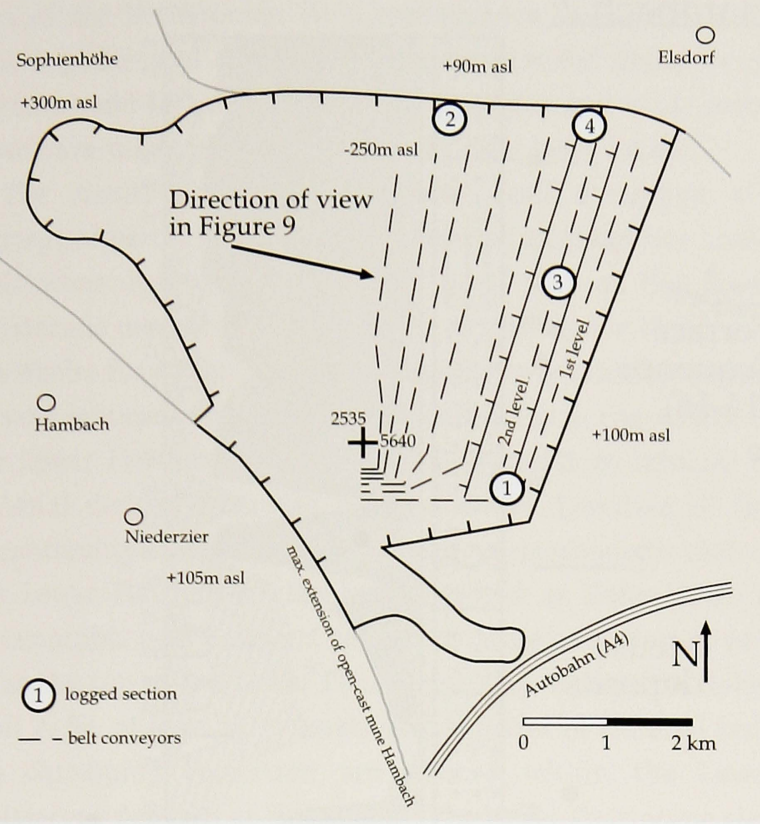

Fig. 8. Map of the open-cast mine Hambach with location of logged and sampled sections, and direction of view in Fig. 9.

one sample at $\pm 31 \mathrm{~m}$ the deposits of strata $14-16$ show again a predominance of unstable spectra. The clay layer in the upper part of stratum $14 \quad 16$ has yielded a mammal fauna belonging to the Middle Pleistocene (MQ 1; Mörs, 2002).

Palaeomagnetic data obtained from samples at the profile Hambach 3 (9 m long, sampled each $10 \mathrm{~cm}$ ) show normal polarity for the deposits of stratum 10 , stratum 11 , and the lowermost $1 \mathrm{~m}$ of stratum 13 . The rockmagnetic analysis of this profile shows a very complicated magneto mineralogy of the deposits. It indicates a complex paragenesis of diagenetic Fe-monosulphides and detrital Fe-oxides.

The section Hambach 4 (14 m long, sampled each $25 \mathrm{~cm}$ ) overlaps with the previously mentioned one and covers the upper part of stratum 11 and stratum 13. The lithology of this profile consists of clay, silt and few fine grained sandy clay layers. The results from the lower part of the section are consistent with those of profile Hambach 3. Stratum 11 shows a normal polarity but about $10 \mathrm{~m}$ above the transition to stratum 13 a change to reversed polarity was detected. Additional heavy mineral analyses have shown that the material contains very stable heavy mineral assemblages.

\section{Discussion}

\section{Type area}

Stratigraphical, petrographical, and palynological investigations at the clay pit Hoher Stall show that the deposits of the Reuver clay, including the underlying sand deposits, are characterised by unstable heavy minerals and belong to the Oebel Beds (Boenigk \& Frechen, 2006). These deposits postdate the deposition of the Reuver Clay s.s. and were deposited after the southward extension of the Rhine catchment into the Alpine area during the Late Pliocene. The extension of the Rhine catchment is well-expressed by a marked change in petrography - switch form predominantly stable tot unstable heavy mineral associations - and typifies the Late Pliocene deposits of the Rhine (Boenigk, 1970; 2002; Hagedorn, 2004).

\section{Open-Cast Mine Hambach:}

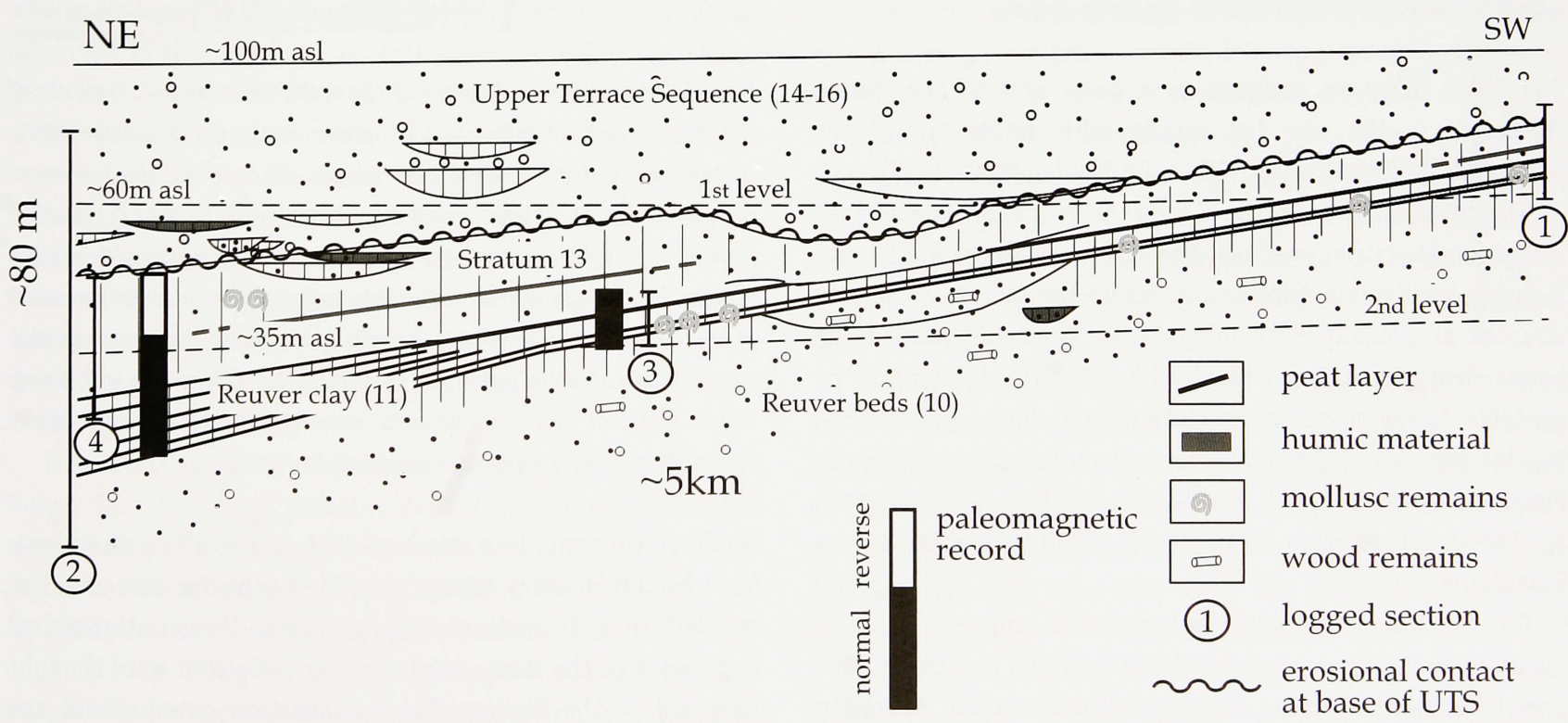

Fig. 9. Scetch of the Plio-Pleistocene succession as exposed at the open-cast mine Hambach with lithology, locations of sampled sections and results of paleomagnetic measurements. The profile Hambach 2 is projected into the plane; not to scale; signatures not included in the legend are according to Fig. 5; see text for further information. 


\section{Hambach 1:}

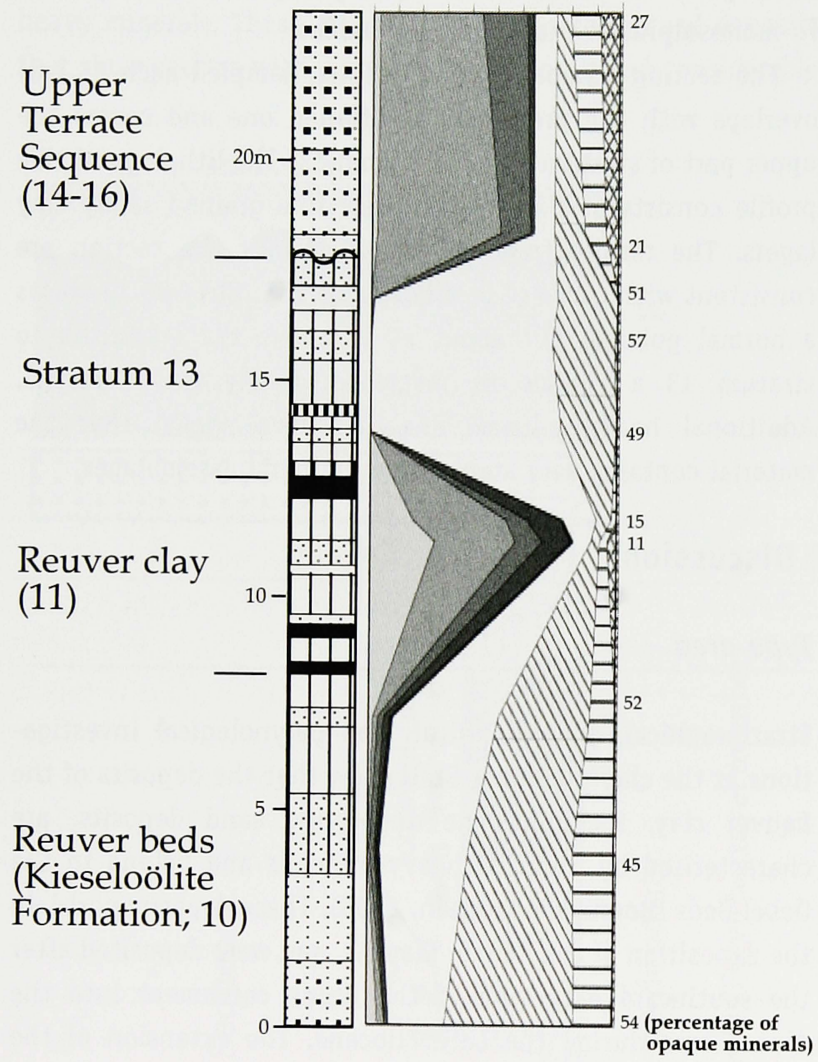

Fig. 10. Heavy mineral diagram of the section Hambach 1. Numbers in brackets refer to the local stratigraphy by Schneider \& Thiele (1965). Stratum 10 contains stable heavy mineral spectra; stratum 11 contains unstable heavy mineral spectra; stratum 13 contains very stable spectra, strata 14 - 16 contain unstable spectra; signatures according to Fig. 6. Note that the vertical interpolation between data points unintendely suggests gradual transitions instead of sudden changes.

The Oebel Beds are assigned as a basal unit of the Waalre Formation in the new lithostratigraphic framework of the Netherlands (Ebbing et al., 2003; De Mulder et al. 2003).

The stratigraphy of the Lower Pleistocene sequence at Hoher Stall is rather complex. The exposures Hoher Stall 1 and 2 show considerable differences despite the fact that they are situated at a distance of only $200 \mathrm{~m}$. The basal part of the Lower Pleistocene deposits at Hoher Stall 1 is typified by unstable heavy mineral associations and forms part of the Tegelen Member of the Waalre Formation. Previously all Lower Pleistocene mixed Rhine Meuse deposits here were assigned as Tegelen Formation (Zonneveld, 1958; Zagwijn \& van Staalduinen, 1975).

Due to their metamorphic heavy mineral content the Lower Pleistocene clay layer exposed at Hoher Stall 1 and the related gravel-free sand layers are assigned to the Stramproy Formation of the revised Dutch lithostratigraphy. The petrography of the deposits points to a provenance in the Belgian Campine area. Here a consequent pattern of small rivers transported reworked
Hambach 2:

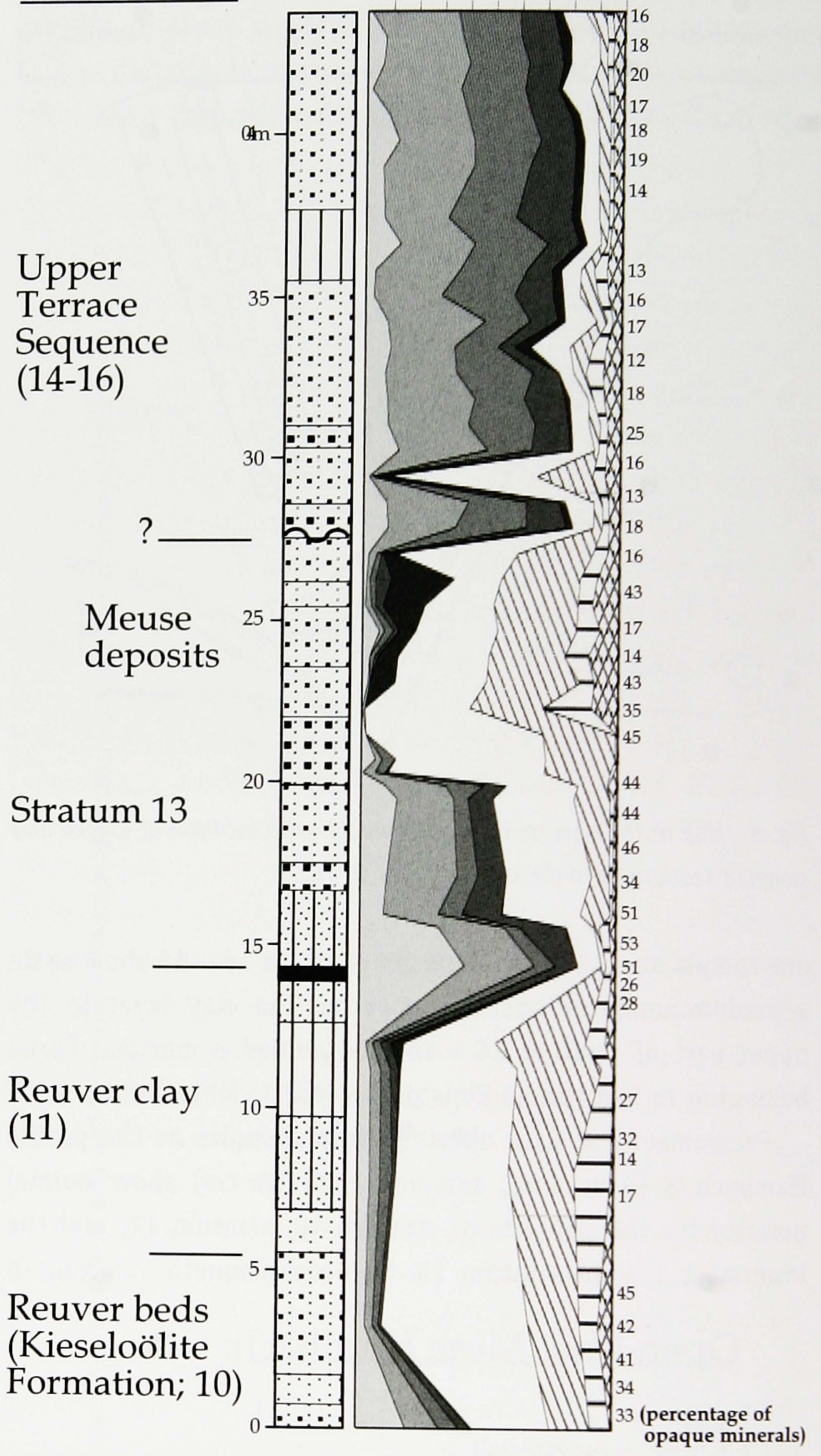

Fig. 11. Heavy mineral diagram of the section Hambach 2. Deposits of the Reuver beds (Kieseloölite Formation; stratum 10) predominantly contain stable heavy mineral assemblages. In contrast, the lowermost sample shows a distinct unstable influx within the Kieseloölite Formation. The Reuver clay (stratum 11) shows both stable and unstable spectra. Unstable as well as very stable heavy mineral assemblages occur in the lower part of stratum 13. Deposits of the Meuse river (metamorphic spectrum) occur in the upper part of stratum 13. One sample with a very stable spectrum occurs in deposits showing unstable spectra (Upper Terrace Sequence?); signatures according to Fig. 6 .

Tertiary sediments into northern and northeastern directions. Such by stable heavy minerals typified deposits were assigned as 'Kedichem Formation' in the former lithostratigraphical framework of the Netherlands and by definition were thought to postdate the Tiglian. The northeastern extension of the small Belgian rivers was only possible because the Meuse followed at the same time its eastern course which resulted in accommodation space for the Belgian rivers in the southeastern 
part of the Netherlands. As a consequence we can conclude that deposition of the Waalre Formation (mixed Rhine-Meuse deposits) and Stramproy Formation ('Belgian' and local rivers) must have taken place synchronously by a large extent.

The results obtained from Hoher Stall 2 support the concept of partly simultaneous deposition of these two Lower Pleistocene Formations. Here, the basal part of the Lower Pleistocene deposits is also assigned as the Tegelen Member of the Waalre Formation. The metamorphic heavy mineral content of sand lenses at the erosional unconformity in the middle of the Lower Pleistocene deposits (Fig. 5) points to influxes of material derived from the "Belgian' rivers. Levelling of the unconformity shows that its elevation corresponds to that of the Lower Pleistocene clay layer exposed at Hoher Stall 1. Metamorphic heavy mineral spectra re-occur just below as well as at the top of the Lower Pleistocene clay deposits in Hoher Stall 2. So, at least three levels with influxes of material from the Stramproy Formation are noticed within the Lower Pleistocene deposits at Hoher Stall. The Lower Pleistocene clay layer at Hoher Stall 2 is interpreted as the infill of a flood basin. It reflects the final phase of the preserved fluvial cycle of a meandering river. The intercalated sand lens is interpreted as crevasse-splay deposit. The underlying coarse-grained gravelbearing deposits are thought to be deposited by a braidedriver system under cold-climatic circumstances (Wolters, 1954; Gibbard et al., 1995), a conclusion that cannot be excluded by the evidence presented here. However, it is clear that the fluvial depositional environment resulted in a highly complex pattern of local facies units alternating with a number of erosional unconformities. Time needed for the development of similar fluvial successions is considerably less than $100 \mathrm{ka}$ (e.g., Weerts, 1996; Miall, 1996). So, it is obvious that any interpretation considering the Lower Pleistocene deposits preserved in the type area as representing a major part of the Early Pleistocene must be regarded as inappropriate.

The palaeomagnetic results of the Hoher Stall pit show a normal polarity for the 0ebel Beds. They therefore can be correlated to the Pliocene Gauss-chron, which confirms earlier results (Van Montfrans,1971; Boenigk et al.,1972). The Lower Pleistocene clay unit at Hoher Stall 1 was probably deposited during the Matuyama-chron at the onset of a normal event as is evidenced by the change from reversed to normal polarity in the uppermost part.

The normal polarity of the lower part of the clay layer at Hoher Stall 2 is most probably caused by post-depositional overprinting as a result of severe oxidation. The clay at Hoher Stall 2 can be assigned to the Matuyama-chron at the onset of a normal event. These results correspond to those of Boenigk et al. (1972). However, their value for chronostratigraphical purposes is limited. For example, the transition from reversed to normal polarity can reflect the initial phase of any Early Pleistocene normal event such as: the Réunion, Olduvai or Jaramillo event.

\section{Hambach}

Petrographic analysis of the succession at the open-cast mine Hambach yielded a number of hitherto unknown PlioPleistocene stratigraphic features. The deposits of the Reuver beds (stratum 10), which are assigned to the Kieseloolite Formation, locally contain material with a predominance of unstable heavy minerals. This influx has also been found in deeper parts of the succession and in the Dutch part of the Ruhr Valley Graben (Westerhoff et al., 2008). These data indicate that the extension of the Rhine's catchment area into the Alpine system took place somewhat earlier in the Late Pliocene than previously thought.

Due to the predominance of unstable heavy minerals the deposits of stratum 11 are assigned to the 0ebel beds due to their petrography with a predominance of unstable heavy minerals. The only exception from this is the Reuver Clay at the section Hambach 2. The deposits show an increased content of stable heavy minerals. This variation is probably due to grain size effects which are regularly noted in fine grained sediments (Boenigk, 1970). Therefore, the Reuver Clay present at the section Hambach 2 is assigned to the 0ebel beds, too. The brown mica-bearing sand deposits underneath stratum 11 in the central part of the excavation contain unstable heavy minerals and are interpreted as a bed-load channel fill which form part of the Oebel Beds here. This part of the sequence at Hambach is well-comparable to the corresponding part at the Hoher Stall pit in the type area near Venlo.

The stable heavy mineral assemblages of the deposits of stratum 13 at Hambach point to a source area in the Eifel mountains, south of the open-cast mine. There are no other deposits known in the Lower Pleistocene of the LRE that can be considered as an equivalent of these local sediments. These deposits are partly intercalated with deposits of the Rhine as evidenced by the occurrence of unstable spectra.

Deposits of the East-Meuse river (Holzweiler Formation, Boenigk, 2002) form another well-recognisable unit and occur within the upper part of stratum 13 of the Lower Pleistocene sequence of the section Hambach 2. The southern distribution limit of the Holzweiler Formation obviously runs through the open-cast-mine (Kemna, 2005).

These results show that the Lower Pleistocene succession at Hambach is formed by three partially interfingering river systems (Rhine, Meuse and a local river). The alternating deposits of the local river and the Rhine occur predominantly in the lower part of the Lower Pleistocene sequence. The last appearance of the local deposits is located above the Holzweiler Formation after a re-occurrence of Rhine deposits (see Hambach 2).

As shown in the Ville area (Boenigk, 1978, 2002; Boenigk \& Frechen, 2006) the boundary between the Lower Pleistocene and the Upper Terrace Sequence cannot easily be recognised in the southern LRE. This is mainly caused by the absence of wellpronounced petrographical changes within the successions. 
The normal magnetic polarity of the deposits of stratum 10 , 11 and the lowermost $1 \mathrm{~m}$ of stratum 13 of profile Hambach 3 shows that they were formed during the Pliocene Gauss-chron. However, the magnetic mineralogy is complex and indicates post-depositional overprinting, probably as a result of diagenesis shortly after deposition.

The switch from normal to reversed polarity within the section Hambach 4 is interpreted as representing the GaussMatuyama boundary. Although this boundary was expected at a much deeper level in the sequence here it occurs approximately $10 \mathrm{~m}$ above the top of the 0ebel beds in the deposits of the local river. The same reversal was found in the upper part of the Oebel beds at the open-cast mine Fortuna in the Ville region (Boenigk et al., 1972, 1979). Both sites show a strong similarity in lithology of the 0ebel Beds. However, we regard the different position of the Gauss-Matuyama boundary as a result of considerable diachronism. This conclusion is supported by evidence form mammal palaeontology. Mammal remains of the Oebel Beds in the Ville region are assigned to the mammal stage MN 16b (Van Kolfschoten et al., 1998). The Oebel Beds at Hambach yield fossils that are assigned to the older stage MN 16a (Mörs et al., 1998; Mörs, 2002).

\section{Lithostratigraphical implications}

A new lithostratigraphy for the LRE is presented in Fig. 12. The three-fold partition of the LRE into a northwestern, a middle, and a southern part as proposed by Boenigk (1978) forms the base of this concept. The revised Dutch lithostratigraphical system has been adopted in the northwestern part of the Lower Rhine Embayment. The middle part of the region is dominated by the Holzweiler Formation (Boenigk, 2002; Boenigk \& Frechen, 2006). The eastern course of the river Meuse prevailed at least until the termination of deposition of the Stramproy Formation in the type area (Westerhoff et al., 2008).

The presented results from Hambach and the knowledge of the Ville region (e.g. Boenigk, 1978) confirm that the lithostratigraphic boundary between Lower and Middle Pleistocene sequences cannot be defined in the southern part of the LRE. It is possible that the lowermost member of the Upper Terrace Sequence (HT 1) forms part of the Lower Pleistocene succession. Therefore, all Rhine deposits with a predominant unstable heavy mineral association are assigned informally as 'Niederrhein-Hauptterrassen Formation' (Boenigk \& Frechen, 2006). The stratotype of this formation is proposed to be at the open-cast mines of the Ville area (Kowalczyk, 1969; Schnütgen, 1974; Boenigk, 1978; Boenigk \& Frechen, 2006). This Formation corresponds to a combination of the Waalre Formation and Sterksel Formation of the Dutch lithostratigraphy. The (informal) name 'Frechen beds' is used to indicate the Lower Pleistocene part of the NiederrheinHauptterrassen Formation. The stratotype for these deposits should be at the open-cast mine Frechen in the Ville area (Kowalczyk, 1969; Boenigk et al., 1972; Boenigk, 1978).

The (informal) name 'Hambach beds' is proposed for the deposits of the local (Eifel) river of stratum 13 as found at Hambach. The stratotype should be located at the open-cast mine Hambach (Kemna, 2005; this paper). The 'Hambach beds' are not considered to represent a separate Formation. They are well-visible in excavations but hard to map by means of borehole data. Here it is proposed that the 'Hambach beds'

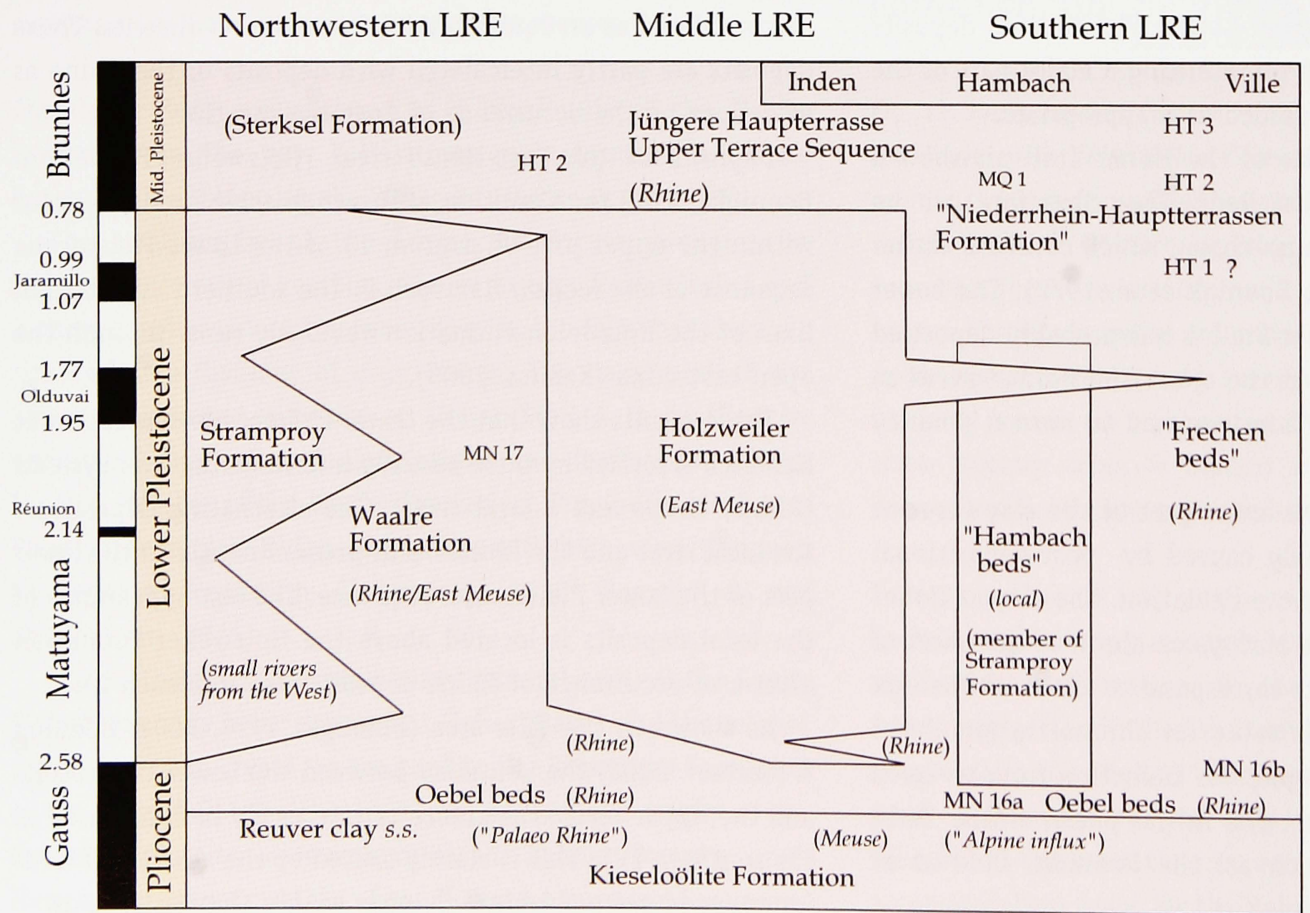

Fig. 12. Lithostratigraphical concept for the Lower Rhine Embayment; magnetic timechart according to Gibbard et al. (2004, see Fig. 2); see text for further information. 
form a member of the Stramproy Formation of the Dutch lithostratigraphy (De Mulder et al., 2003; Ebbing et al., 2003) because this formation integrates local deposits.

The results from the clay pit Hoher Stall in the type area near Venlo fit well into the new Dutch lithostratigraphic system (Ebbing et al., 2003). Other findings from the Ruhr block (Westerhoff et al., 2008) support this concept as well. As a consequence the chronostratigraphic system of the Early Pleistocene as used in large parts of Europe becomes an object of doubt. This system is largely based on the former concepts of lithostratigraphical and petrographic subdivisions of Lower Pleistocene deposits. Now that a new lithostratigraphy is presented, the necessity for revising the chronostratigraphic framework becomes increasingly important.

\section{Conclusions}

Several new lithostratigraphic units have been identified in the Lower Rhine Embayment.

The old Dutch lithostratigraphic framework (Zonneveld, 1958; Zagwijn \& van Staalduinen, 1975) has to be abandoned.

The new lithostratigraphic concept as set up for the LRE shows a strong correlation with the recently revised lithostratigraphy of the Netherlands.

Severe doubt exists on the validity of the existing, pollenbased bio- and chronostratigraphic subdivision in stages and substages of the Early Pleistocene of northwestern Europe as defined some 50 years ago in the type area near Venlo.

\section{Acknowledgements}

Completion of this work would never have been possible without contributions, help and advice by many colleagues and friends. W. Boenigk, Cologne, and W.E. Westerhoff, Utrecht, have helped me much in many discussions. R. Stritzke, Krefeld, and M. Höcker, Cologne have contributed to this work by providing data. S. Asmus and W. Bauendahl, both RWEPower AG, Cologne, have made the field work in the open-cast mines possible. F. von der Hocht, Cologne, H. Weerts and P. Cleveringa (TNO, Utrecht) and T. van Kolfschoten (Leiden) have helped with additional information and discussions. Phil Gibbard and Henk Weerts are thanked for their thorough review of an earlier manuscript of this paper.

\section{References}

Abraham, M., 1994. Untersuchungen zur sedimentologischen Entwicklung der fluviatilen Deckschichten (Miozän, Pliozän) der Rheinischen Braunkohle. Bonner Geowissenschaftliche Schriften 15: 1-227.

Aguirre, E. \& Pasini, G., 1985. The Plio-Pleistocene boundary. Episodes 8: 116120.

Ahorner, L., 1962. Untersuchungen zur quartären Bruchtektonik der Niederrheinischen Bucht. Eiszeitalter und Gegenwart 13: 24-105.

Ashraf, A.R. \& Mosbrugger, V., 1995. Palynologie und Palynostratigraphie des Neogens der Niederrheinischen Bucht. Teil 1: Sporen. Unter Mitwirkung von U. Hebbeker. Palaeontographica B 235: 61-173.

Ashraf, A.R. \& Mosbrugger, V., 1996. Palynologie und Palynostratigraphie des Neogens der Niederrheinischen Bucht. Teil 2: Pollen. Palaeontographica, B 241: 1-98.

Boenigk, W., 1970. Zur Kenntnis des Altquartärs bei Brüggen. Sonderveröffentlichungen Geologisches Institut Universität Köln 17: 1-141.

Boenigk, W., 1974. Correlation of the oldest Pleistocene of the Lower Rhine Basin with that of the Netherlands. IUGS-UNESCO International Geological. Correlation Programme, Project 73/I/24 'Quaternary Glaciations in the Northern Hemisphere', Report. No. 1: 43-49.

Boenigk, W., 1978. Gliederung der altquartären Ablagerungen in der Niederrheinischen Bucht. Fortschritte Geologie Rheinland und Westfalen 28: 135212.

Boenigk, W., 1981a. Die Gliederung der tertiären Braunkohlendeckschichten in der Ville (Niederrheinische Bucht). Fortschritte Geologie Rheinland und Westfalen 29: 193-263.

Boenigk, W., 1981b. Das Quartär der Bohrung Heidhausen. Sonderveröffentlichungen Geologisches Institut Universität Köln 41: 9-18.

Boenigk, W., 1983. Schwermineralanalyse. Stuttgart (Enke).

Boenigk, W., 2002. The Pleistocene drainage pattern in the Lower Rhine Basin. Netherlands Journal of Geosciences 81/2: 201-209.

Boenigk, W., Kowalczyk, G. \& Brunnacker, K., 1972. Zur Geologie des Ältestpleistozäns der Niederrheinischen Bucht. Mit Beiträgen von E.K. Kempf, A. Koči und V. Ložek. Zeitschrift deutsche geologische Gesellschaft 123 (1): 119-161.

Boenigk, W., von der Brelie, G., Brunnacker, K., Koči, A., Schlickum, W.R. \& Strauch, F., 1974. Zur Pliozän-Pleistozän-Grenze im Bereich der Ville (Niederrheinische Bucht). Newsletter on Stratigraphy 3 (4): 219-241.

Boenigk, W., Koči, A. \& Brunnacker, K., 1979. Magnetostratigraphie im Pliozän der Niederrheinischen Bucht. Neues Jahrbuch Geologie Paläontologie Monatshefte 1979 (9): 513-528.

Boenigk, W. \& Frechen, M., 2006. The Pliocene and Quaternary Fluvial Archives of the Rhine System. Quaternary Science Reviews 25 (5/6): 550-574.

Breddin, H., 1955. Die Gliederung der altdiluvialen Hauptterrasse von Rhein und Maas in der Niederrheinschen Bucht. Der Niederrhein 3/4: 1-4.

De Mulder, E.F.J., Geluk, M.C., Ritsema, I., Westerhoff, W.E. \& Wong, Th.E. 2003. De ondergrond van Nederland. Geologie van Nederland deel 7, Utrecht (TNO-NITG), 379 pp.

Ebbing, J.H.J., Weerts, H.J.T. \& Westerhoff, W.E., 2003. Towards an integrated land-sea stratigraphy of the Netherlands. Quaternary Science Reviews 22 1579-1587. 
Edelman, C.H., 1933. Petrologische provincies in het Nederlandse Kwartair. Thesis, University of Amsterdam, 104 pp.

Fliegel, G. \& Stoller, J., 1910. Jungtertiäre und altdiluviale pflanzenführende Ablagerungen im Niederrheingebiet. - Jahrbuch Preußische Geologische Landes-Anstalt 31 (I): 227-257.

Florschütz, F., \& van Someren, A.M.H., 1948. Microbotanische verschillen tussen de klei van Reuver en de klei van Tegelen. Geologie en Mijnbouw, Nieuwe Serie 10: 68-69.

Gibbard, P.L., West, R.G., Zagwijn, W.H., Balson, P.S., Burger, A.W., Funnel, B.M., Jeffery, D.H., de Jong, J., van Kolfschoten, T., Lister, A.M., Meijer, T., Norton, P.E.P., Preece, R.C., Rose, J., Stuart, A.J., Whiteman, C.A. \& Zalasiewicz, J.A., 1991. Early and Early Middle Pleistocene correlations in the southern North Sea Basin. Quaternary Science Reviews 10: 23-52.

Gibbard, P.L., Krook, L. \& Vandenberghe, J., 1995. Early Pleistocene depositional environments and stratigraphy at öbel (Brüggen), NordrheinWestfalen, Germany. Mededelingen Rijks Geologische Dienst 52: 83-96.

Gibbard, P.L., Boreham, S., Cohen, K.M. \& Moscariello, A. (comp.), 2004. Global chronostratigraphical correlation table for the last 2.7 million years (v.2004.b). Internet resource http://www-qpg.geog.cam.ac.uk/.

Hermanns, $K$., 1992. Untersuchungen in neogenen Tonschichten des Rheinischen Braunkohlenreviers, südliche Niederrheinische Bucht. Bonner Geowissenschaftliche Schriften 2: 1-203.

Heumann, G. \& Litt, T., 2002. Stratigraphy and paleoecology of the Late Pliocene and Early Pleistocene in the open-cast mine Hambach (Lower Rhine Basin). Netherlands Journal of Geosciences 81/2: 193-199.

Kemna, H.A., 2005. Pliocene and Lower Pleistocene stratigraphy in the Lower Rhine Embayment, Germany. Kölner Forum 14: 1-113.

Kemna, H.A., \& Westerhoff, W.E., 2007. Remarks on the palynology-based chronostratigraphical subdivision of Pliocene terrestrial deposits in NWEurope. Quaternary International 164-165: 184-196.

Klostermann, J., 1983. Die Geologie der Venloer Scholle (Niederrhein). Geologisches Jahrbuch A 66: 3-115.

Kowalczyk, G., 1969. Zur Kenntnis des Altquartärs der Ville (südliche Niederrheinische Bucht). Sonderveröffentlichungen Geologisches Institut Universität Köln 18: 1-147.

Krutzsch, W., 1988. Kritische Bemerkungen zur Palynologie und zur klimastratigraphischen Gliederung des Pliozäns bis tieferen Altpleistozäns in Süd-, Südwest-, Nordwest- und pro parte Mitteleuropa sowie die Lage der Pliozän/Pleistozän-Grenze in diesem Gebiet. Quartärpaläontologie 7: 7-51.

Kurtz, E., 1913. Die Verbreitung der diluvialen Hauptterrassenschotter von Rhein und Maas in der Niederrheinischen Bucht. Verhandlungen Naturhistorischer Verein Rheinland Westfalen 70: 87-108.

Mange, M.A. \& Maurer, H.F.W., 1991. Schwerminerale in Farbe. Stuttgart (Enke).

Meijer, T., 1998. References of relevant publications about Pliocene and Early Pleistocene deposits in the Netherlands. Mededelingen Nederlands Instituut Toegepaste Geowetenschappen TN0 60: 579-602.

Miall, A.D., 1996. The geology of fluvial deposits. Springer, pp.582.

Mörs, T., 2002. Biostratigraphy and paleoecology of continental Tertiary vertebrate faunas in the Lower Rhine Embayment (NW-Germany). Netherlands Journal of Geosciences 81/2: 177-183.
Mörs, T., von Königswald, W. \& von der Hocht, F., 1998. Rodents (Mammalia) from the late Pliocene Reuver Clay of Hambach (Lower Rhine Embayment, Germany). Mededelingen Nederlands Instituut Toegepaste Geowetenschappen TNO 60: 135-160.

Nota, D.J.G., 1956. Sedimentpetrologische Untersuchungen altpleistozäner Ablagerungen im Gebiet von Tegelen, Niederlande. Geologie en Mijnbouw, Nieuwe Serie 18: 402-410.

Reid, C. \& Reid, E.M., 1915. The Pliocene flora of the Dutch-Prussian border. Mededelingen Rijksopsporing van Delfstoffen 6: 1-178.

Reid, E.M., 1920. A comparative review of Pliocene floras, based on the study of fossil seeds. Quaterly Journal Geological Society 76: 145-161.

Schlickum, W.R. \& Strauch, F., 1979. Die Land- und Süßwassermollusken der pliozänen Deckschichten der rheinischen Braunkohle. Abhandlungen Senckenbergische Naturforschende Gesellschaft 536: 1-144.

Schneider, H. \& Thiele, S., 1965. Geohydrologie des Erftgebietes. Düsseldorf (Min. f. Ernährung, Landwirtsch. u. Forsten NRW), 185 pp.

Schnütgen, A., 1974. Die Hauptterrassenfolge am linken Niederrhein aufgrund der Schotterpetrographie. Forschungsberichte Nordrhein-Westfalen 2399: 1-149.

Tesakov, A.S., 1998. Voles of the Tegelen fauna. Mededelingen Nederlands Instituut Toegepaste Geowetenschappen TN0 60: 71-134.

Urban, B., 1978a. Vegetationsgeschichtliche Untersuchungen zur Gliederung des Altquartärs der Niederrheinischen Bucht. Sonderveröffentlichungen Geologisches Institut Universität Köln 34: 1-165.

Urban, B., 1978b. The interglacial of Frechen I/Rheinland - a section of the Tiglian A type. Geologie en Mijnbouw 57 (3): 401-406.

Vinken, $R$., 1988. The Northwest European Tertiary Basin. Geologisches Jahrbuch A 100: 1-508.

Van Kolfschoten, T., van der Meulen, A.J. \& Boenigk, W., 1998. The late Pliocene rodents (mammalia) from Frechen, Germany. Mededelingen Nederlands Instituut Toegepaste Geowetenschappen TN0 60: 161-172.

Van Montfrans, H.M., 1971. Palaeomagnetic dating in the North Sea Basin. Earth Planetary Science Letters 11: 226-236.

Van der Verk, I.M. \& Florschütz, F., 1950. Nederland in het Ijstijdvak. Utrecht (de Haan), 289 pp.

Van der Vlerk, I.M. \& Florschütz, F., 1953. The palaeontological base of the subdivision of the Pleistocene in the Netherlands. Verhandelingen. Koninglijk Nederlands Akademie Wetenschappen Afdeling Natuurkunde, 1e Reeks 20 (2): $1-58$

Weerts, H.J.T., 1996. Complex Confining Layers. Nederlands Geografische Studien 213: 1-189.

Westerhoff, W.E., 2004. Upper Pliocene and Lower Pleistocene Rhine-Meuse deposits in the Tegelen-Reuver type area. With contributions by H.A. Kemna. In: DEUQUA meeting 2004, Nijmegen, Excursion guide: 79-130.

Westerhoff, W.E., Cleveringa, P., Meijer, T., van Kolfschoten, T. \& Zagwijn, W.H., 1998. The Early Pleistocene fluvial (clay) deposits in the Maalbeek pit near Tegelen, the Netherlands. Mededelingen Nederlands Instituut Toegepaste Geowetenschappen TN0 60: 35-70.

Westerhoff, W.E., Boenigk, W. \& Kemna, H.A., 2008. The confluence area of Rhine, Meuse, and Belgian rivers: Late Pliocene and Early Pleistocene fluvial history of the northern Lower Rhine Embayment. Netherlands Journal of Geosciences 87/1: 107-125. 
Wolters, $\boldsymbol{R}_{\text {., }}$ 1954. Ausbildung und Lagerung der pliozän-pleistozänen Grenzschichten im niederrheinischen Grenzgebiet von Niederkrüchten/Brüggen. Geologisches Jahrbuch 69: 339-348.

Zagwijn, W.H., 1957. Vegetation, climate and time-correlations in the early Pleistocene of Europe. Geologie en Mijnbouw, Nieuwe Serie 19 (7): 233-244.

Zagwijn, W.H., 1960. Aspects of the Pliocene and Early Pleistocene vegetation in the Netherlands. Mededelingen Geologische Stichting C-III-1 (5): 1-78.

Zagwijn, W.H., 1963. Pollen-analytic investigations in the Tiglian of the Netherlands. Mededelingen Geologische Stichting, Nieuwe Serie 16: 49-71.

Zagwijn, W.H., 1974. Bemerkungen zur stratigraphischen Gliederung der pliopleistozänen Schichten des niederländisch-deutschen Grenzgebietes zwischen Venlo und Brüggen. Zeitschrift deutsche geologische Gesellschaft 125: $11-16$.

Zagwijn, W.H., 1985. An outline of the Quaternary stratigraphy of the Netherlands. Geologie en Mijnbouw 64: 17-24.

Zagwijn, W.H., 1989. The Netherlands during the Tertiary and the Quaternary. A case history of coastal lowland evolution. Geologie en Mijnbouw 68: 107-120.

Zagwijn, W.H., 1998. Borders and boundaries: a century of stratigraphical research in the Tegelen-Reuver area of Limburg (the Netherlands). Mededelingen Nederlands Instituut Toegepaste Geowetenschappen TN0 60: $19-34$.

Zonneveld, J.I.S., 1947. Het Kwartair van het Peelgebied en naaste omgeving (een sedimentpetrologische studie). Mededelingen Geologische Stichting C-IV-3: 1-223.

Zonneveld, J.I.S., 1959. Lithostratigrafische eenheden in het Nederlandse Pleistoceen. Mededelingen Geologische Stichting Nieuwe Serie 12: 31-64. 